\title{
The Influence of Teacher Teaching and Guidance of Parents on Student Achievement with Mediation of Learning Motivation in Santo Yoseph Denpasar
}

\author{
Ida Ayu Sasmitha Putri, Putu Ngurah Suyatna Yasa and Ni Luh Anik Puspa Ningsih \\ Masters in Management, Postgraduate Program, Universitas Warmadewa \\ bali-indonesia-sasmithaputri7@gmail.com
}

\begin{tabular}{|l|}
\hline \multicolumn{1}{|c|}{ Published: 30/09/2020 } \\
\hline How to cite (in APA style): \\
Putri, Ida Ayu Sasmitha, Yasa, Putu Ngurah Suyatna, \& Ningsih, Ni Luh Anik Puspa. (2020). The Influence of Teacher \\
Teaching and Guidance of Parents on Student Achievement with Mediation of Learning Motivation in Santo Yoseph \\
Denpasar. Jurnal Ekonomi dan Bisnis Jagaditha, 7(2), 138-147. doi: https://doi.org/10.22225/jj.7.2.2498.66-75 \\
\hline
\end{tabular}

\begin{abstract}
Abstrak- The study aims to determine the influence of teacher teaching methods on student achievement, the influence of teacher teaching methods on the motivation of Learning, the influence of parental guidance on the motivation of Learning, the influence of parental guidance on student achievement, the influence of motivation to learn to students achievements, how the motivation to learn to influence teacher teaching methods on student achievement. This study was conducted on the SMAK of Santo Yoseph Denpasar. In this research student achievement is influenced by teacher teaching methods, parental guidance and motivational learning. The respondent in this study was 120 students of SMAK Santo Yoseph Denpasar. Data analysis is done using PLS (partial least square). The results showed that teacher teaching methods are positively and significantly impactful to student achievement. Then, teacher teaching methods have positive and significant influence on student achievement, proven. Furthermore, parental guidance positively and insignificant towards learning motivation, on student achievement, not proven. Learning motivation positive and significant impact on student achievement. The motivation to learn to process the relationship between teacher teaching methods to student achievement, is not proven. The motivation to learn to publish the relationship between parents ' guidance on student achievement, proven.
\end{abstract}

Keywords: Motivational Learning, Parental Guidance, Student Achievement, Teacher Teaching methods

\section{INTRODUCTION}

Student achievement is very important because learning achievement is one illustration of the level of success of the activities during the lesson. One of the goals in the learning process is to achieve an achievement in learning. Learning achievements are learning outcomes obtained by students after following the teaching and learning process carried out by the teacher. There are three teachers for children, namely teachers at school, parents at home and the environment.

It is not surprising that family background has significant power to explain disparities in educational participation and achievement of Lam \& Ducreux (2013) revealing that there is a positive relationship between communication and academic achievement; as communication improves, academic performance increases.
There is also a positive relationship between the highest level of parental education and parental assistance, monitoring, and the higher the level of parental education, the more parents involved.

According to Shulruf \& Wang (2011), child development is influenced by the home environment, such as mother-child communication, effective disciplinary methods, home safety and educational activities provided by parents. Parenting practices are the most influential factor influencing children's outcomes. Research conducted by Alcott (2017) revealed that teacher encouragement has the greatest influence on students who are most likely to be on the margin for university attendance. According to Rashid \& SaeedUzZaman (2018), teachers have a key role to play in providing a learning environment that 
encourages their students to excel academically. Most of the responsibility for the quality of learning therefore falls on the personality and attitude of the teacher. Then, Vahdany, Sabouri, \& Ghafarnian (2015) in his study showed that Rasht high school (SMA) students have a positive attitude towards their language teacher, and there is a significant relationship between student-teacher attitudes and student achievement. Encouragement from external factors can have an impact on student achievement but even then it must be supported by students' motivation to learn. Nashar (2004) revealed that the learning motivation of students in each learning activity plays an important role in increasing student achievement in certain subjects. Harahap (2016) revealed that there is a positive and significant influence of learning motivation on student achievement. Hamdu \& Agustina (2019) revealed that there is a positive and significant relationship between learning motivation and student achievement.

Based on the theory and empirical evidence described above, it can be seen the importance of teacher teaching methods and parental guidance in a child's life, especially for the child's achievement. According to Sutikno (2103) states the Teaching Method is ways of presenting subject matter conducted by educators so that the learning process occurs in students in an effort to achieve goals. However, the results of the National Survey on Life Experience of Children and Adolescents show two out of three children have experienced violence. One in 11 girls and one in 17 boys experience sexual violence (Kompas, 11/1/2020). In addition, Law No. 14/2005 on teachers and lecturers (UU GD) stipulates teacher professionalism based on four competencies and certifications obtained from teacher professional education (PPG). Based on observations made by the author of class XII students at St. Joseph's Public High School showed that students have a good close relationship with parents as always attentive by asking about activities in school and helping in the learning process. In addition, the expected teaching methods are those that are not boring (monotonous), modern and more into practice. As for the teaching methods of the teacher $44 \%$ of children were not satisfied, $22 \%$ were satisfied and $22 \%$ were quite satisfied.

\section{CONCEPT AND HYPOTHESIS}

Based on the description from previous studies, it can be described that the conceptual framework proposed from this study is as follows.

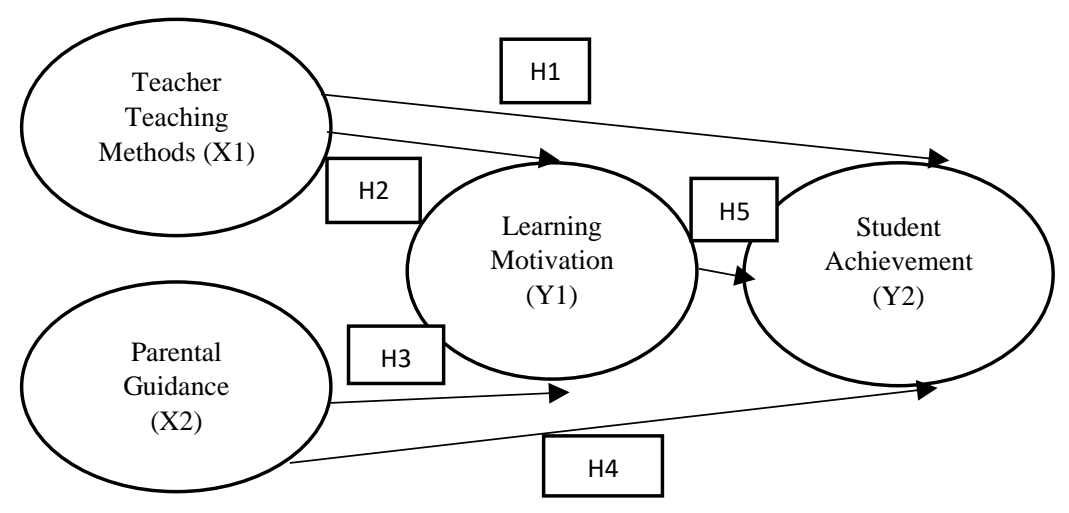

Figure 1.

Conceptual Framework for Research

Based on the theories, concepts and previous studies relating to student achievement as described in the literature review section, it can be formulated and explained the hypotheses in this study as follows. H1: Teacher teaching methods have a positive and significant effect on student achievement. H2: Teacher teaching methods have a positive and significant effect on learning motivation. H3: Parental guidance has a positive and significant effect on learning motivation. H4: Parental guidance has a positive and significant effect on student achievement. H5: Learning motivation has a positive and significant effect on student 
achievement. H6: Learning motivation acts as a mediation between teacher teaching methods and student achievement. H7: Learning motivation acts as a mediation between parental guidance and student achievement.

\section{Population and Research Samples}

1) Population

The population in the study were students at the St. Joseph High School Denpasar.

2) Samples

Students of class X and XI of St. Joseph High School in Denpasar with criteria selection. To determine the sample size of the population, the Slovin formula (Husein Umar, 2011;383) can be used.

\section{Research variable}

Supporting variables in this study are 1) Teacher Teaching Method, 2) Parental Guidance, and 3) Student Achievement. Teacher Teaching Method Variables (X1) and Parental Guidance (X2) are independent variables while Learning Motivation Variables (Y1) as mediation Student Achievement Variables (Y2) are dependent variables.

\section{Definition of Variable Operations Student Achievement (Y1)}

Learning achievement is the result or achievement of one's efforts in the teaching and learning process in the form of numbers, letters, symbols and sentences. In this study the indicators used to assess student achievement are.

1) Mid-semester exam results

2) The value of individual assignments and the value of group assignments

3) Homework (PR)

4) The activity value includes the activity value in the class

5) Semester exam results

\section{Motivation to learn}

Learning motivation is all efforts to encourage both from within and from outside in the process of gaining knowledge. Indicators of learning motivation (Uno, 2010) can be classified as follows.

1) The desire and desire to succeed.
2) There is encouragement and needs in learning.

3) There are hopes and ideals of the future.

4) There is an appreciation in learning.

5) There are interesting activities in learning.

6) The existence of a conducive learning environment.

\section{Teacher Teaching Methods (X1)}

Teacher teaching methods are systematic ways that are carried out by educators (teachers) in the teaching-learning process. Indicators according to Government Regulation no. 19 of 2005 used to measure the teaching methods of teachers in this study are as follows.

1) Understanding the characteristics of students with physical, social-emotional, and intellectual disorders who need special handling.

2) Mastering the basic principles of teaching and learning that educate.

3) Develop a curriculum that encourages student involvement in learning.

4) Assess the process and learning outcomes that refer to the whole purpose of education.

5) Mastering teaching material in the curriculum

6) Strong, stable, mature, wise and authoritative personality abilities that will set an example for participants and have good morals.

\section{Parental Guidance (X2)}

Parental guidance is a special process of assistance given by parents in the learning process, developing potentials, recognizing oneself and being responsible for children's lives. Indicators that will be used in this study (Hasbullah, 2013).

1) Give love

2) Give moral obligations

3) Give social responsibility

4) Nurturing and raising children

5) Providing education, knowledge and skills

6) Provide learning facilities

7) Helps learning difficulties

8) Give an example or example

9) Give a reward or punishment

10) Give freedom

\section{METHOD}


This study was conducted on the SMAK of Santo Yoseph Denpasar. In this research student achievement is influenced by teacher teaching methods, parental guidance and motivational learning. The respondent in this study was 120 students of SMAK Santo Yoseph Denpasar. Data analysis is done using PLS (partial least square) (Latan \& Ghozali, 2012). Then, data are presenting in form of table and after that the data was interpreted descriptively

\section{RESULTS AND DISCUSSION Characteristics of Respondents}

This study was conducted to determine the effect of teacher teaching methods and parental guidance on student achievement by mediating learning motivation at the St. Joseph Senior High School Denpasar. Data collection was carried out through distributing questionnaires to 120 students in grade $\mathrm{X}$ and $\mathrm{XI}$.

\section{Construction Reliability Test}

The results of the reliability test of the research instrument showed that the value of alpha cronbachs in each construct was $>0.60$ which means that the reliability of all research variables was categorized as good and accepted.

\section{Test Validity of Research Instruments}

Table 1

Test the validity of Constructing Item Teacher Teaching Methods (X1), Parental Guidance (X2), Learning Motivation (Y1), Student Achievement (Y2)

\begin{tabular}{|c|c|c|c|}
\hline No & Indicators of Teacher Teaching Methods (X1) & $\begin{array}{l}\text { Correlation } \\
\text { coefficient }\end{array}$ & $\begin{array}{c}\text { Informatio } \\
n\end{array}$ \\
\hline 1 & $\begin{array}{l}\text { The teacher tries to understand each student's difficulties and } \\
\text { provides a joint solution (X1.1) }\end{array}$ & 0,865 & Valid \\
\hline 2 & $\begin{array}{l}\text { The teacher is able to explain the subject matter well and is easily } \\
\text { understood (X1.2) }\end{array}$ & 0,894 & Valid \\
\hline 3 & $\begin{array}{l}\text { Teachers provide opportunities for students to be actively involved } \\
\text { in learning and teaching activities (X1.3) }\end{array}$ & 0,720 & Valid \\
\hline 4 & $\begin{array}{l}\text { The teacher has the ability to be steady, stable, mature, wise and } \\
\text { authoritative who will set an example for participants-as well as } \\
\text { having good morals (X1.4) }\end{array}$ & 0,821 & Valid \\
\hline 5 & The teacher masters teaching material in the curriculum (X1.5) & 0,831 & Valid \\
\hline No & Indicators, Parental Guidance (X2) & $\begin{array}{l}\text { Correlation } \\
\text { coefficient }\end{array}$ & $\begin{array}{c}\text { Informatio } \\
n\end{array}$ \\
\hline 1 & Parents give love (X2.1) & 0,850 & Valid \\
\hline 2 & Parents give moral obligations (X2.2) & 0,837 & Valid \\
\hline 3 & Parents give social responsibility (X2.3) & 0,829 & Valid \\
\hline 4 & Parents nurture and raise you (X2.4) & 0,730 & Valid \\
\hline 5 & Parents give Education, knowledge and skills (X2.5) & 0,839 & Valid \\
\hline 6 & Parents provide learning facilities (X2.6) & 0,760 & Valid \\
\hline 7 & Parents set an example or example (X2.7) & 0,855 & Valid \\
\hline 8 & Parents help learning difficulties (X2.8) & 0,719 & Valid \\
\hline 9 & Parents give rewards or punishments (X2.9) & 0,653 & Valid \\
\hline 10 & Parents give freedom (X2.10) & 0,339 & Valid \\
\hline No & Learning Motivation Indicator (Y1) & $\begin{array}{l}\text { Correlation } \\
\text { coefficient }\end{array}$ & $\begin{array}{l}\text { Informatio } \\
n\end{array}$ \\
\hline 1 & Persevering in the task (Y1.1) & 0,598 & Valid \\
\hline 2 & Resilient in facing difficulties (Y1.2) & 0,669 & Valid \\
\hline 3 & Showing interest in various problems (Y1.3) & 0,659 & Valid \\
\hline
\end{tabular}


The Influence of Teacher Teaching and Guidance of Parents on Student Achievement with Mediation of Learning Motivation in Santo Yoseph Denpasar

\begin{tabular}{|l|l|c|c|}
\hline 4 & Prefer to work independently (Y1.4) & 0,650 & Valid \\
\hline 5 & Fast bored with routine tasks (Y1.5) & 0,393 & Valid \\
\hline 6 & Can defend his opinion (Y1.6) & 0,556 & Valid \\
\hline No & Student Performance Indicator (Y2) & $\begin{array}{c}\text { Correlation } \\
\text { coefficient }\end{array}$ & $\begin{array}{c}\text { Informatio } \\
\text { n }\end{array}$ \\
\hline 1 & $\begin{array}{l}\text { Mid Semester Exam Results Above KKM (Minimum completeness } \\
\text { criteria) (Y2.1) }\end{array}$ & 0,770 & Valid \\
\hline 2 & Assignment score above KKM (Y2.2) & 0,749 & Valid \\
\hline 3 & Good class activeness (Y2.3) & 0,628 & Valid \\
\hline 4 & Semester exam results above KKM (Y2.4) & 0,794 & Valid \\
\hline
\end{tabular}

\section{Evaluation of Measurement Model (Measurement Model/outer Model) Convergent Validity}

Convergent validity is a criterion in measuring the validity of indicators that are reflexive. This evaluation is done through an examination of the outer loading coefficient of each indicator of its latent variable. The analysis shows that all indicator values indicate outer loadings that the estimation results have shown are valid, which are> 0.50 and statistically significant. These results can be seen further in Figure 2 and Figure 3.

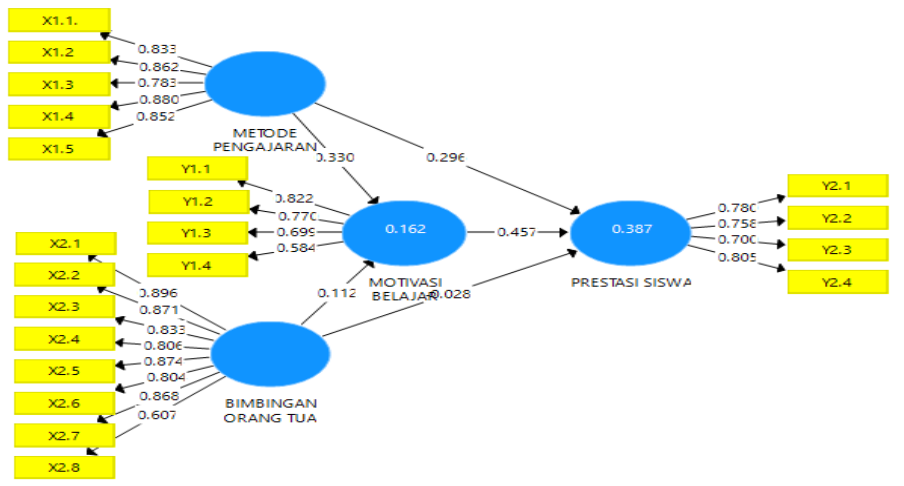

Figure 2.

Outer Loading and Path Analysis Estimated Results

While the results of calculations regarding the results of its significance test (boothstrapping) before the reconstruction can be seen in Figure 3.

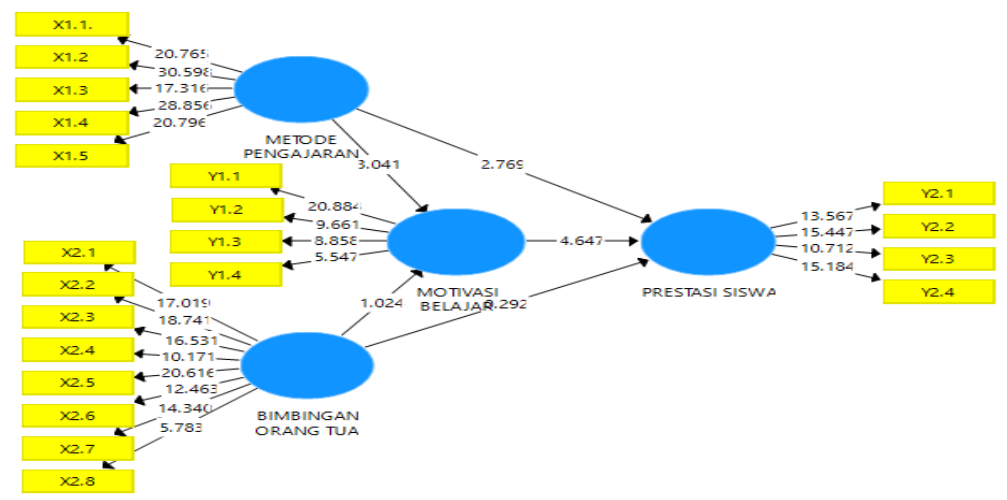

Figure 3.

Boothstrapping (Statistical Test) 


\section{Discriminant Validity}

Measurement of the validity of the indicators that form latent variables can also be done through discriminant validity by looking at the value of $\sqrt{ } \mathrm{AVE}$ and AVE. Indicators are considered valid if the AVE value of each construct> 0.50 and the value of $\sqrt{\mathrm{AVE}}$ throughout the construct> the value of correlation between variables (Latan \& Ghozali, 2012:78-79). The analysis showed that the AVE value of all constructs> 0.50 and the value of AVE for parental guidance $=0.825$; teaching method $=0.843$; learning motivation $=$ 0.724 and learning achievement $=0.762$ is greater than the correlation value between constructs that is between 0.431 to 0.689 so it is declared valid based on discriminant validity criteria.

\section{Composite Reliability and Cronbach Alpha}

A measurement can be said to be reliable, if the composite reliability and Cronbach alpha have a value greater than 0.70 . Composite reliability and Cronbac alpha are a measure of reliability among indicator blocks in the research model. The analysis results show that the composite reliability value of each construct shows a value greater than 0.70 . From the Cronbach Alpha value, only learning motivation has a slightly lower value of 0.70 , so overall the entire construct is declared valid based on composite reliability.

\section{Evaluation of Structural Models Through R- Square (R2)}

According to Latan \& Ghozali (2012), an RSquare (R2) value of 0.67 is classified as a strong model, R-Square (R2) of 0.33 moderate model, and R-Square (R2) of 0, 19 is classified as a weak model. The results of the analysis showed based on the Chin criteria (Lathan and Ghozali, 2012: 85), then the model included the weak model criteria, the meaning was the variation of teaching methods and parental guidance was able to explain variations in learning motivation by $16.20 \%$ percent, the remaining $83.80 \%$ percent is explained by variations of other variables outside the analyzed model. Student achievement has an R2 value of 0.387 based on Chin criteria (Latan \& Ghozali, 2012: 85), then the model includes moderate criteria, the meaning is variation of teaching methods, parental guidance and learning motivation is able to explain variations in performance by $38.70 \%$ percent, the remaining $61.30 \%$ percent is explained by variations in other variables outside the analyzed model.

\section{Evaluation of Structural Models through Q- Square Predictive Relevance (Q2)}

Q-Square Predictive Relevance (Q2) is a measure of how well the observations made give results to the research model. The value of Q-Square is = 1- $(1$ - R12) $(1-\mathrm{R} 22)=1-(1$ $0.162)(1-0.387)=1-0.514=0.486$, based on these results, the estimation model is included in the criteria strong, meaning that $48.60 \%$ of variation in endogenous constructs can be predicted by variations in exogenous constructs.

\section{Evaluation of Structural Models through Goodness of Fit (GoF)}

Goodness of Fit (GoF) is a measurement of the accuracy of the overall model (global), because it is considered to be a single measurement from the measurement of the outer model and measurement of the inner model. Calculation with GoF shows an average value of R 2 of 0.275 while an average of $\sqrt{ } \mathrm{AVE}$ of 0.789 , then a GoF value of A $\sqrt{ } \mathrm{R} 2 *$ A. $\sqrt{ }$ AVE $=\sqrt{ } 0.275 * 0.789=\sqrt{ } 0.217=0.466$ This means that the global model is strong predictive (large ).

\section{Path Analysis and Testing Hypotheses}

Path Analysis and Testing The expected hypothesis is that Ho is rejected or sig $<0.05$ (or t-statistic value $>1.96$ with a significance level of 0.05).

Table 2.

Path Analysis and Testing Statistics

\begin{tabular}{|c|c|c|c|c|c|c|}
\hline CONSTRUCT & $\begin{array}{c}\text { Original } \\
\text { Sample } \\
(\mathbf{O})\end{array}$ & $\begin{array}{c}\text { Sample } \\
\text { Mean } \\
(\mathbf{M})\end{array}$ & $\begin{array}{c}\text { Standard } \\
\text { Deviation } \\
\text { (STDEV) }\end{array}$ & $\begin{array}{c}\text { T Statistics } \\
(\mid \mathbf{O} / \text { STERR|) }\end{array}$ & $\begin{array}{c}\mathbf{P} \\
\text { Values }\end{array}$ & Information \\
\hline $\begin{array}{c}\text { PARENT GUIDANCE -> } \\
\text { LEARNING MOTIVATION }\end{array}$ & 0,112 & 0,144 & 0,108 & 1,034 & 0,302 & $\begin{array}{l}\text { Positive But } \\
\text { Not Significant }\end{array}$ \\
\hline
\end{tabular}




\begin{tabular}{|c|c|c|c|c|c|l|}
\hline $\begin{array}{c}\text { PARENT GUIDANCE -> } \\
\text { STUDENT ACHIEVEMENTS }\end{array}$ & $-0,028$ & $-0,026$ & 0,117 & 0,290 & 0,772 & $\begin{array}{l}\text { Negative and } \\
\text { Not Significant }\end{array}$ \\
\hline $\begin{array}{c}\text { TEACHING METHODS -> } \\
\text { LEARNING MOTIVATION }\end{array}$ & 0,330 & 0,326 & 0,108 & 2,905 & 0,004 & $\begin{array}{l}\text { Positive and } \\
\text { Significant }\end{array}$ \\
\hline $\begin{array}{c}\text { TEACHING METHOD -> } \\
\text { STUDENT ACHIEVEMENTS }\end{array}$ & 0,296 & 0,295 & 0,117 & 3,067 & 0,002 & $\begin{array}{l}\text { Positive and } \\
\text { Significant }\end{array}$ \\
\hline $\begin{array}{c}\text { STUDY MOTIVATION -> } \\
\text { STUDENT ACHIEVEMENTS }\end{array}$ & 0,457 & 0,462 & 0,124 & 4,565 & 0,000 & $\begin{array}{l}\text { Positive and } \\
\text { Significant }\end{array}$ \\
\hline
\end{tabular}

As shown in the Table 2 that Parental guidance has a positive effect of 0.112 on learning motivation and the relationship is not significant at the 0.05 level because the P-value is $0.302>0.05$. Parental guidance has a negative effect on student achievement of -0.028 , and the relationship is not significant at the 0.05 level with a P-value of $0.772>0.05$. The teaching method has a positive effect of 0.330 on learning motivation and the relationship is significant at the 0.05 level with a P-value of $0.04<0.05$. The teaching method has a positive effect on student achievement by 0.296 and the relationship is significant at the 0.05 level with a P-value of $0.02<0.05$. Learning motivation has a positive effect on student achievement by 0.457 and the relationship is significant at the 0.05 level with a P-value of $0.00<0.05$.

\section{The Effect of Teacher Teaching Methods on Student Achievement at St. Joseph's Senior High School Denpasar}

The results of the analysis showed that the teaching methods of the teacher had a positive and significant effect on the achievement of the students of the St. Joseph Senior High School in Denpasar. This positive and significant influence shows that the better the teacher's teaching methods, the student's achievement increases. This means that when teachers master teaching materials in the curriculum and provide opportunities for students to be actively involved in learning and teaching activities, the value of student assignments increases above the minimum completeness criteria (KKM) and student activity in the classroom either.

The results support the results of research conducted by Alcott (2017) revealed that teacher encouragement can help the advancement of student education especially those with parents with low education. Rashid \& SaeedUzZaman (2018) revealed that teachers have a key role to play in providing a learning environment that encourages their students to excel academically.

\section{The Effect of Teacher Teaching Methods on Students' Learning Motivation at St. Joseph's High School in Denpasar}

The results of the analysis show that the teaching methods of the teacher have a positive and significant influence on the motivation to learn students at the St. Joseph Senior High School Denpasar. This positive and significant influence indicates that the better the teacher's teaching methods, the higher the student's achievement. The reality in the field shows that when the teacher masters the material in the curriculum, the teacher gives the opportunity for students to be actively involved in learning and teaching activities so students are more diligent in facing assignments and tenacious in facing difficulties.

The results of this study support research conducted by Sucia (2017) stated that there is a positive and significant influence of teacher communication on student motivation. Sutardi (2016) revealed that there was a positive and significant influence between teacher competencies on learning outcomes. Raisyifa \& Sutarni (2016) revealed the positive and significant influence of teacher teaching methods on learning motivation. Robih, Suratman, \& Soesatyo (2017) stated that there is an influence between teachers and learning motivation. Korur \& Eryilmaz (2019) in his research revealed that students would be disappointed if their teacher avoided asking questions, difficulties in solving problems and teacher's inconsistent attitude.

The Effect of Parental Guidance on Students' Learning Motivation at St. Yoseph SMAK Denpasar

The results of the analysis show that parental guidance has a positive but not significant effect on the motivation to study students at the St. 
Joseph Senior High School in Denpasar. This positive and insignificant influence means parents maintain, nurture, give love and learning facilities, students are happy but unable to increase student motivation. This can arise because although parents provide facilities, love, nurture and nurture, but parents have not been able to help students' learning difficulties that can motivate students.

The results of this study are not in line with the results of research conducted by Ningsih (2013) stated that the role of parents in motivating children in school is as a motivator supporting children to progress, facilitators bridging between children with teachers and the community and also the mediator.

The Effect of Parental Guidance on the Achievement of St. Joseph's High School Students

The results of the analysis show that parental guidance has a negative and not significant effect on the achievement of students of the St. Joseph Senior High School in Denpasar. This negative effect is due to the characteristics of respondents aged 15-18 years, adolescents who are growing up. This can also occur when parents provide facilities, maintain and grow, but on the other hand parents are less able to set an example or example and help students' learning difficulties as well as the lack of appreciation of parents in giving rewards that can improve student achievement.

The results of this study are not in line with the results of research conducted by Sulaeman (2016) revealed a positive and significant influence between parental guidance and student achievement. However, the results of this study are consistent with Hendriyanto (2016).

\section{The Effect of Learning Motivation on the Achievement of St. Joseph's High School Students in Denpasar}

The results of the analysis show that learning motivation has a positive and significant effect on the achievement of students of the St. Joseph Senior High School in Denpasar. This positive and significant influence shows that the better the motivation to learn can improve student achievement at the St. Joseph Senior High School Denpasar. This shows that students are diligent and tenacious in facing tasks so that the value of their assignment is above the minimum completeness criteria (KKM).

The results of this study are in line with the results of research conducted by Makrifat (2012) revealing a positive and significant influence between intrinsic and extrinsic motivation on student achievement. Sutardi (2016) revealed that there is a positive and significant influence of learning motivation on student achievement. Harahap (2016) revealed a positive and significant influence between learning motivation and student achievement. Rizkiana (2014) showed that there was a partially significant influence between parents' socioeconomic status, learning motivation, and learning discipline on learning achievement. Kumala (2016) revealed the positive and significant influence of learning motivation on student achievement.

\section{Motivation for Learning Role as Mediation Between Teacher Teaching Methods Against Student Achievement of St. Joseph's Senior High School Denpasar}

Based on the criteria of Hair Jr, Black, Babin, \& Anderson (2010) learning motivation is a partial mediation between teacher teaching methods and student achievement. Learning motivation variable has not been able to explain the relationship between teacher teaching methods and student achievement because the direct relationship between teacher teaching methods and student achievement is significant, and student learning motivation has a significant direct relationship to student achievement. The meaning of the role of mediating variables here shows that the effect of teaching methods on student achievement has not been able to be conveyed properly by learning motivation, in other words learning motivation does not mediate the direct relationship of teacher teaching methods to student achievement at St. Joseph's High School Denpasar.

The results of this study are not in line with the results of research conducted by Rizqi (2015) expressed that indirectly the pedagogical competence of teachers and learning facilities through learning motivation as a mediating variable influences learning outcomes. Sinaga (2015) revealed through the mediation test of 
student learning motivation, the basic skills of teaching teachers also have an influence on improving student learning outcomes.

\section{Motivation for Learning Role as Mediation Between Parental Guidance Against the Achievement of Students of Santo Yoseph SMAK Denpasar}

Learning motivation is a full mediation between parental guidance and student achievement. The findings of this study reveal that parental guidance has an important effect on learning motivation, while learning motivation has an important impact on the achievement of students of the St. Joseph Senior High School Denpasar. The meaning of the role of mediation here shows that the influence of parental guidance on student achievement is well conveyed by learning motivation.

The results of this study are in line with the results of research conducted by Mauliddya \& Rustam (2019) revealing a positive and significant effect of mediating learning motivation on parental guidance on student achievement. Muhidin (2018) revealed there is a positive influence of parental support on student achievement mediating learning motivation. Hedyanti, Sudarmiatin, \& Utaya (2016) revealed the variable of learning motivation strengthens the direct effect of parenting parents on students' social studies learning achievement. Astuti (2019) revealed that learning motivation mediates the effect of parents' attention on student learning outcomes.

\section{CONCLUSION}

Based on the description and results of the study can be concluded that the effect of teacher teaching methods on student achievement has a positive and significant influence. The effect of teacher teaching methods on learning motivation has a positive and significant effect. The influence of parental guidance on learning motivation has a positive but not significant effect. The influence of parental guidance on student achievement has a negative and insignificant influence. The influence of learning motivation on student achievement has a positive and significant influence. This positive and significant influence shows that the better the motivation to learn can improve student achievement at the St. Joseph Senior
High School Denpasar. Learning motivation acts as a mediation between the teaching methods of teachers on the students' achievement of the Santo Yoseph Senior High School Denpasar showing the results that learning motivation is a partial mediation between the teaching methods of teachers on student achievement. Learning motivation acts as a mediation between parental guidance on student achievement in St. Yoseph Denpasar Senior High School showing the results that learning motivation is a full mediation between parental guidance on student achievement.

\section{REFERENCES}

Alcott, B. (2017). Does Teacher Encouragement Influence Students' Educational Progress? A Propensity-Score Matching Analysis. Research in Higher Education, 58(7), 773804.

Astuti, R. S. (2019). Efek Mediasi Paralel Disiplin Belajar dan Motivasi Belajar Siswa Pada Pengaruh Perhatian Orang Tua terhadap Hasil Belajar Siswa pada Mata Pelajaran Ekonomi: Survey Pada Siswa Kelas XI IPS SMA Negeri Kota Bandung Wilayah A. Universitas Pendidikan Indonesia.

Hair Jr, J. F., Black, W. C., Babin, B. J., \& Anderson, R. E. (2010). Multivariate Data Analysis (7th ed.). United States: Pearson.

Hamdu, G., \& Agustina, L. (2019). Pengaruh Motivasi Belajar Siswa terhadap Hasil Belajar IPA di Sekolah Dasar (Studi Kasus terhadap Siswa Kelas IV SDN Tarumanagara Kecamatan Tawang Kota Tasikmalaya). Jurnal Penelitian Pendidikan, 12(1), 90-96.

Harahap, Y. (2016). Pengaruh Motivasi Belajar dan Disiplin Belajar terhadap Prestasi Belajar Alquran Hadis Kelas X MAN Binjai TA. 2015-2016. Universitas Islam Negeri Sumatera Utara.

Hasbullah. (2013). Dasar-dasar Ilmu Pendidikan. Jakarta: Rajagrafindo Persada.

Hedyanti, W. N., Sudarmiatin, \& Utaya, S. (2016). Pengaruh Pola Asuh Orangtua Terhadap Prestasi Belajar Ips Melalui Motivasi Belajar (Studi Pada Siswa Kelas IV, V, VI Gugus 2 Kecamatan Ngantang Kabupaten Malang). Jurnal Pendidikan: Teori, Penelitian, Dan Pengembangan, 1(5), 865-873.

Hendriyanto, M. N. (2016). Peran Bimbingan Orang Tua Terhadap Prestasi Belajar Siswa Kelas XI Teknik Kendaraan Ringan di SMK 45 Wonosari. Universitas Negeri Yogyakarta.

Korur, F., \& Eryilmaz, A. (2019). Interaction 
between Students' Motivation and Physics Teachers' Characteristics: Multiple Case Study. Qualitative Report, 23(12), 30543083.

Kumala, S. N. (2016). Pengaruh Keterampilan Dasar Mengajar Guru dan Motivasi Belajar terhadap Hasil Belajar Siswa Kelas X di Man Se-Kabupaten Blitar Tahun Ajaran 2015/2016. IAIN Tulungagung.

Lam, B. T., \& Ducreux, E. (2013). Parental Influence and Academic Achievement among Middle School Students: Parent Perspective. Journal of Human Behavior in the Social Environment, 23(5), 579-590

Latan, H., \& Ghozali, I. (2012). Partial Least Squares: Konsep, Teknik dan Aplikasi SmartPLS 2.0 M3. Semarang: Badan Penerbit Universitas Diponegoro.

Makrifat. (2012). Pengaruh Motivasi Belajar terhadap Prestasi Siswa Pada Bidang Studi PAI di SMA-IT Wahdah Islamiyah Makassar. Universitas Islam Negeri Alauddin.

Mauliddya, S. A., \& Rustam, A. (2019). Peran Dukungan Sosial Orang Tua terhadap Prestasi Akademis melalui Mediasi Motivasi Belajar Intrinsik. Gadjah Mada Journal of Psychology (GamaJoP), 5(2), 166.

Muhidin, R. (2018). Penamaan Marga dan sistem Sosial Pewarisan Masyarakat Sumatera Selatan (Naming Clan and Social System of Transfer to People in South Sumatera). Jurnal Kebudayaan, 13(2), 161-175.

Nashar, H. (2004). Peranan Motivasi dan Kemampuan Awal dalam Kegiatan Pembelajaran. Jakarta: Delia Press.

Ningsih, S. (2013). Peran Orang Tua dalam Motivasi Belajar Anak di Sekolah. Universitas Islam Negeri Sunan Kaliaga.

Raisyifa, D. N., \& Sutarni, N. (2016). Pengaruh Kinerja Mengajar Guru terhadap Motivasi Belajar Siswa. Jurnal Pendidikan Manajemen Perkantoran, 1(1), 90-98.

Rashid, M. A. ul H., \& SaeedUzZaman. (2018). Effects of Teacher's Behavior on Academic Performance of Students. ResearchGate, 115.

Rizkiana, A. (2014). Pengaruh Status Sosial Ekonomi Orang Tua, Motivasi Belajar, Disiplin Belajar Terhadap Prestasi Belajar pada Siswa SMK Barunawati Surabaya. Jurnal Ekonomi Pendidikan Dan
Kewirausahaan, 2(2).

Rizqi, L. (2015). Peran Motivasi Belajar dalam Memediasi Pengaruh Kompetensi Pedagogik Guru dan Fasilitas Belajar terhadap Hasil Belajar Mata Pelajaran Ekonomi (Studi Kasus Pada Siswa Kelas XI IPS Madrasah Aliyah Negeri 1 Semarang Tahun Ajaran 2014/2015). Universitas Negeri Semarang.

Robih, W., Suratman, B., \& Soesatyo, Y. (2017). The Effects of Self-Efficacy, The Role of Teacher, Parents Participation to Student's Learning Motivation At Vocational High School North Surabaya. Journal of Economics and Economic Education Research, 18(2), 1-9.

Shulruf, B., \& Wang, G. (2011). Parent Influence on Outcomes for Children: HIPPY as a CostEffective Option (English version). Revista de Cercetare Si Interventie Sociala, 34, 7-20.

Sinaga, H. B. (2015). Pengaruh Keterampilan Dasar Mengajar Guru terhadap Hasil Belajar Siswa Melalui Mediasi Motivasi (Studi pada Mata Pelajaran Ekonomi Kelas XI IPS di SMA Negeri 22 Kota Bandung). Universitas Pendidikan Indonesia.

Sucia, V. (2017). Pengaruh Gaya Komunikasi Guru terhadap Motivasi Belajar Siswa. Komuniti: Jurnal Komunikasi Dan Teknologi Informasi, $8(2), 112-126$.

Sulaeman, A. (2016). Pengaruh Bimbingan Orang Tua terhadap Prestasi Belajar Siswa pada Mata Pelajaran Pendidikan Agama Islam di Kelas IV SD Negeri Kota Kulon III Garut Kota. Jurnal Inklusi, 6(2).

Sutardi, S. (2016). Pengaruh Kompetensi Guru, Motivasi Belajar, dan Lingkungan Keluarga terhadap Hasil Belajar Mata Pelajaran Ekonomi. Jurnal Pendidikan IPS, 3(2), 188198.

Sutikno, S. (2103). Belajar dan Pembelajaran. Surakarta: Holistica.

Uno, H. H. B. (2010). Teori Motivasi \& Pengukurannya: Analisis di Bidang Pendidikan. Jakarta: Bumi Aksara.

Vahdany, F., Sabouri, N. B., \& Ghafarnian, S. (2015). The Relationship among EFL Teachers, Students' Attitudes \& Their Teaching-learning Achievements in English. Academy Publication, 5(12), 2625-2630. 